\title{
Dampak Penggunaan Gadget terhadap Kemampuan Interaksi Anak Sekolah Dasar pada Situasi Pandemi Covid-19
}

\author{
Muhammad Iqbal Ulil Amri ${ }^{1}$, Reza Syehma Bahtiar ${ }^{2}$, Desi Eka Pratiwi ${ }^{3}$ \\ 1,2,3Pendidikan Guru Sekolah Dasar, Fakultas Bahasa dan Sains \\ Universitas Wijaya Kusuma Surabaya \\ Email: q. balamri09@gmail.com ${ }^{1}$, syehma@gmail.com ${ }^{2}$, pratiwidesi27@gmail.com ${ }^{3}$
}

\begin{abstract}
The purpose of this article is to examine the impact of the use of gadgets for elementary school children and their benefit in a pandemic situation Covid-19. The design of this study uses literature review. The steps in the literature review are (1). Topic search; (2). Specify a title; (3). Conclusions. Writing analysis techniques in writing literature review are; (1). data collection; (2). data reduction; (3). drawing conclusions. In this writing, there is an analysis in the form of negative and positive impacts. Impact: The children can interact with your friends wherever you are, you can learn online through in pandemic Covid-19, negative impact children more often play a gadget play from a friend about the environment so that children become individualistic
\end{abstract}

Keywords : gadget, interaction social, Elementary school children, Covid-19 pandemic.

\begin{abstract}
Abstrak
Tujuan penulisan artikel ini adalah untuk mengetahui dampak yang ditimbulkan dari penggunaan gadget bagi anak Sekolah Dasar beserta manfaat gadget dalam situasi pandemi Covid-19. Desain penelitian ini menggunakan kajian literatur. Langkah dalam kajian literatur adalah (1) pencarian topik; (2) menentukan judul; (3) penyimpulan. Teknik analisis penulisan dalam penulisan kajian literatur adalah: (1) pengumpulan data; (2) reduksi data; (3) penarikan kesimpulan. Pada penulisan ini, terdapat hasil analisis berupa dampak negatif dan positif. Dampak positif adalah anak bisa berinteraksi dengan teman dimanapun berada, bisa belajar online disituasi pandemi Covid-19, sedangkan dampak negatif anak lebih sering bermain gadget daripada bermain dengan teman lingkungan sekitar sehingga menjadi anak individualis.
\end{abstract}

Kata Kunci : gadget, kemampuan interaksi, anak Sekolah Dasar, Covid-19. 


\section{PENDAHULUAN}

Perkembangan teknologi pada era sekarang ini banyak mengalami kemajuan. Perkembangan tersebut ditandai dengan munculnya suatu barang yang disebut gadget sehingga memudahkan kegiatan manusia misalnya dapat mencari informasi dengan cepat. Menurut (Syahudin, 2019) gadget adalah suatu benda elektronik yang digunakan sebagai komunikasi oleh manusia seperti handphone, komputer dan lainnya. Pada awalnya penggunaan gadget hanya digunakan orang dewasa akan tetapi dijaman modern ini gadget banyak juga digunakan pada anak anak

Penggunaan gadget untuk anak usia Sekolah Dasar tersebut bisa berdampak positif maupun negatif yaitu anak dapat mencari materi pembelajaran dengan mudah dan dapat berkomunikasi jarak jauh selain itu bisa berdampak negatif anak lebih sering memainkan gadget daripada bermain dan berinteraksi dengan teman sekitar hal ini bisa menyebabkan anak menjadi seorang individualis, sehingga orang tua harus mengawasi anak saat bermain gadget.

Pada saat ini dunia mengalami musibah dengan munculnya virus corona yang sangat menakutkan, virus ini tidak terlihat oleh mata manusia karena ukurannya sangat kecil apabila terinfeksi virus corona akan mengalami sesak nafas hingga paling parah kematian. Banyak orang yang terdampak virus ini baik dalam hal ekonomi, sosial dan juga pendidikan. Dampak virus corona dalam bidang sosial yaitu manusia dilarang melakukan kegiatan yang berkelompok/ dibatasi sehingga dalam bidang pendidikan juga terdampak yaitu banyak Sekolah Dasar meliburkan semua muridnya untuk mencegah Covid-19 semakin meluas maka pembelajaran yang awalnya tatap muka tetapi sekarang ini memakai pembelajaran online menggunakan gadget.

Berdasarkan paparan di atas, dapat dirumusan masalah sebagai berikut :

a. Apa saja dampak yang ditimbulkan akibat dari pengunaan gadget terhadap kemampuan interaksi sosial siswa sd ?

b. Apa saja manfaat penggunaan gadget pada saat pandemi bagi anak Sekolah Dasar?

\section{Gadget}

Gadget adalah suatu barang elektronik yang berfungsi untuk komunikasi satu dengan yang lainnya tidaklah susah seiring kemajuan jaman. gadget memiliki fitur terbaru yaitu; games, internet, video. Pada kemunculanya Gadget ialah sebuah istilah kata bahasa Inggris yang berarti suatu barang elektronik kecil yang mempunyai macam fungsi khusus (Chusna, 2017). pendapat lain juga menyebutkan bahwa Gagdet merupakan suatu bentuk nyata dari adanya perkembangan teknologi pada zaman sekarang ini. Hal ini mempengaruhi pada pola pikir maupun perilaku manusia (Putri Hana Pebriana, 2017). Gadget mempunyai 
banyak manfaat bila dipakai dengan bijak dan sesuai fungsinya, asalkan pada saat anak menggunakan gadget harus dalam pemantauan orang tua. (Marpaung, 2018).

\section{Aplikasi Dalam Gadget}

Macam macam aplikasi pada gadget adalah sebagai berikut:

a. Aplikasi yang mendukung bagi pembelajaran yaitu :

youtube, quiz, Microsoft 306.

Zoom, Ruang guru.com.

b. Sosial media

Whatsapp, facebook, line

c. Game

Catur, mobil-mobilan, TTS

Jadi dari penjelasan diatas bisa diartikan bahwa gadget merupakan sebuah barang elektronik modern yang mempunyai banyak manfaat yaitu untuk berkomunikasi, mencari berita dan bermain games.

\section{Anak Usia Sekolah Dasar}

Pada usia ini anak berada di sekitar umur 6 sampai 12 tahun, tahap ini termasuk kedalam tahap operasional konkret. Menurut piaget tahap operasional konkret adalah kondisi dimana anak-anak sudah bisa menggunakan akalnya untuk berfikir secara logis terhadap sesuatu yang bersifat nyata. Pada tahapan ini, pemikiran logis menggantikan pemikiran intuitif (naluri) dengan syarat pemikiran tersebut dapat diaplikasikan menjadi contoh-contoh yang konkret atau spesifik, adapun kekurangan dari pada tahap ini ketika anak diberi pemasalahan yang bersifat abstrak (secara verbal) dengan tidak adanya suatu objek nyata, maka ia anak mengalami kesusahan bahkan tidak bisa memecahkan masalah yang terjadi. Anak mengalami perubahan yang sangat signifikan. Perubahan tersebut meliputi 3 aspek yaitu; perkembangan fisik, kemampuan dan psikososial. Perkembangan fisik anak ditandai dengan adanya perubahan berat badan dan tinggi anak.

Perkembangan kognitif adalah perkembangan yang berhubungan dengan tingkat kecerdasan anak yang ditandai dengan perubahan anak mampu berperan aktif saat belajar. Perkembangan psikososial yaitu anak mudah beradaptasi dengan lingkungan sekitar. Perkembangan sosial pada anak Sekolah Dasar dilihat dari keberhasilan saat berinteraksi, bergaul, dan menyesuaikan diri dengan lingkungan. Perkembangan psikologi juga mempengaruhi emosi dalam diri anak.

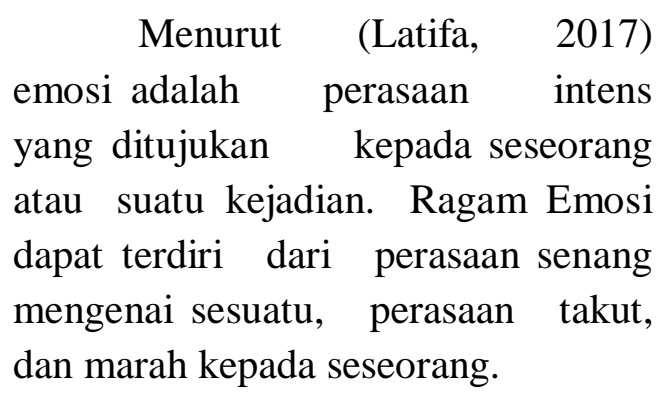

\section{Interaksi Sosial}

Manusia Sebagai makhluk sosial pasti membutuhkan bantuan dari orang lain selama hidupnya. Menurut Menurut (Xiao, 2018) interaksi sosial yaitu hubungan dinamis yang saling berkaitan antar manusia. Meliputi hubungan antar 
sesama individu, antara kelompok satu dengan kelompok lain, dan juga hubungan antar seseorang dengan kelompok.

\section{Jenis-Jenis interaksi sosial}

interaksi sosial dapat terbagi menjadi 3 jenis sebagai berikut:

\section{a. Interaksi sosial antar} sesama individu.

Interaksi sosial ini bisa terjadi pada saat dua individu bertemu dan berkomunikasi. Misalnya bersalaman dengan teman dan saling mengobrol saat pulang sekolah.

b. Interaksi antara individu dengan kelompok.

Interaksi sosial ini terjadi pada situasi yang sudah ditentukan. Misalnya: guru memberi pelajaran ke siswa dikelas, kepala sekolah sedang rapat dengan para guru

c. Interaksi antara kelompok dan kelompok

Kelompok merupakan satu-kesatuan yang saling berinteraksi dengan kelompok lainnya, begitu juga dengan interaksi juga terjadi pada suatu kelompok tersebut. Interaksi yang terjadi pada kelompok dapat dilihat dari tim sepak bola yang saling bekerja sama untuk memenangkan pertandingan.

Interaksi sosial dalam kehidupan sehari hari dapat terwujud di berbagai bentuk yaitu pergaulan seperti bersalaman, menyapa dan komunikasi dengan orang lain.

\section{Masa Pandemi Covid-19}

Saat ini dunia digemparkan dengan adanya penyakit Corona Virus atau disebut Covid-19. Pada awalnya Corona Virus ini terjadi dinegara china bisa menyebar ke seluruh negara. Menurut (Yuliana, 2020) coronavirus ialah virus RNA Strain tunggal positif, coronavirus termasuk golongan ordo nidovirales. Struktur coronavirus membentuk menyerupai kubus dengan protein di permukaanya.

Coronavirus merupakan virus RNA yang berukuran partikel 120$160 \mathrm{~nm}$. Virus ini awalnya menginfeksi hewan antaranya adalah kelelawar dan unta. Sebelum terjadinya wabah COVID-19, ada 2 macam coronavirus yang bisa menginfeksi ke manusia, yaitu: Severe Acute Respiratory Illness Coronavirus (SARS-CoV), dan Middle East Respiratory Syndrome Coronavirus (MERS-CoV) (Susilo et al., 2020). Gejala yang muncul dari coronavirus ini yaitu gejala sesak nafas, demam dan batuk. Pada kasus COVID-19 yang berat bisa menyebabkan pneumonia, sindrom pernapasan akut, gagal ginjal hingga kematian. (yurianto,2020). Adapun cara untuk mencegah penyebaran coronavirus yaitu melalui mencuci tangan secara teratur dengan menggunakan sabun dan air bersih, memakai masker, serta menghindari kontak secara dekat dengan orang 
yang menunjukkan tanda-tanda seperti batuk dan bersin.

Dari penjelasan diatas dapat diartikan coronavirus adalah suatu penyakit/ Virus menyerang saluran pernapasan yang ditandai dengan batuk, pilek dan demam yang bisa menyebabkan kematian manusia.

\section{METODOLOGI}

Penulisan dalam artikel ini menggunakan kajian literatur. Menurut (Marzali, 2017) kajian literatur adalah suatu pencarian kepustakaan dengan cara membaca berbagai sumber buku, jurnal, dan terbitan terbitan lain yang berhubungan dengan topik penulisan, sehingga menciptakan suatu karya tulis. Studi pustaka ialah kata lain dari kajian pustaka, kajian teoritis, menurut (Melfianora, 2017) Yang dimaksud kajian kepustakaan adalah pencariaan dengan menggunakan karya tertulis yang diantaranya hasil penelitian yang dipublikasikan maupun yang belum. Sumber data yang dibutuhkan dari kajian ini tidak harus ke lapangan tetapi memanfaatkan sumber prpustakaan dalam memperoleh data.

Dari penjelasan diatas maka dapat diartikan kajian literatur adalah sebuah penulisan yang yang berasal dari penelusuran sumber jurnal,buku, seminar dan bertujuan untuk menperkenalkan kajian-kajian baru dalam topik tertentu.

\section{Langkah langkah penulisan kajian literatur}

Menurut (Marzali, 2017) langkah-langkah dalam menulis kajian literatur sebagai berikut :

a. Mulai mencari kata kunci, bahan materi, dan referensi, yang berhubungan.

b. Membaca abstrak penelitian relevan, yang bisa diperoleh dari sumber, jurnal, buku, dan seminar.

c. Mencatat hasil bacaan dengan referensi bibliografi secara rinci.

d. Membuat kajian pustaka dan disusun secara tematis yang sesuai teori-teori dan konsep-konsep penting berhubungan dengan topik.

e. Pada akhir kajian pustaka, tuliskan pandangan umum tentang topik yang dilakukan.

\section{Teknik analisis kajian literatur}

Analisis ini menggunakan pengumpulan sumber data, reduksi data kemudian melakukan penarikan kesimpulan. Untuk menganalisis penulisan ditentukan kebaruan pustaka yang terkait dengan topik penulisan.

a. Pengumpulan sumber data

Penulisan jurnal literatur ini bersumber dari data jurnal-jurnal, dan sumber internet.

b. Reduksi data

Setelah mendapatkan data, sumber data tersebut dianalisis untuk diambil materi yang relevan dan berkaitan dengan judul.

c. Penarikan kesimpulan 
Selanjutnya semua sumber data dirangkum secara rinci untuk diambil kesimpulan.

\section{HASIL DAN PEMBAHASAN}

Dari hasil penelitian yang dilakukan (Kamil, 2016) didapatkan informasi bahwa gadget berpengaruh terhadap anak Sekolah Dasar seperti anak tidak saling berbicara saat berkumpul bersama sehingga menghilangkan kebiasaan yang telah ada.

Dalam penelitian (Syifa et al., 2019) ini didapatkan informasi dari 10 murid kelas 5 yang memakai gadget dengan durasi lebih dari 2 jam sehari mengalami perubahan sikap dan perkembangan moral. Untuk perubahan sikap adalah anak yang mudah marah, suka membantah orang tua, pengaruhnya ke perkembangan moral anak menjadi malas melakukan aktivtas sehari-hari, dan waktu belajar yang berkurang penyebabnya terlalu sering menonton youtube. Menurut penjelasan dari (Suntoro, 2013) bahwa pemakaian gadget dengan waktu yang tidak dibatasi bisa menjadikan anak antisosial lupa berinteraksi dengan lingkungan sekitar tempat tinggal. Hal ini dapat menyebabkan hilangnya interaksi dengan lingkungan sekitar.

Pada masa pandemi Covid-19 penggunaan gadget diperlukan untuk pembelajaran online karena bisa belajar dimanapun tanpa datang ke sekolah. Hal itu didukung dalam penelitian (Purwanto et al., 2020) bahwa proses pembelajaran disaat pandemi Covid-19 berdampak ke murid, orang tua dan juga guru. Bagi murid perlu beradaptasi dengan kebiasaan baru yaitu pembelajaran jarak jauh melalui aplikasi whatshaap berinteraksi dengan tidak secara langsung. Bagi orang tua pengeluaran biaya tambahan untuk membeli kuota untuk belajar anaknya. Bagi guru tidak semua guru bisa handal dalam mengoperasikan gadget sebagai media pembelajaran. Pendapat lain juga dalam penelitian (Wahyu Aji Fatma Dewi, 2020) pada saat kondisi pandemi Covid-19 anak bisa melakukan pembelajaran online dengan gurunya dirumah masing masing melalui aplikasi zoom, whatsaap dan google doc sehingga tanpa harus datang sekolah secara langsung sehingga dapat mencegah penularan Covid-19.

Hasil menyatakan bahwa pemakaian gadget pada anak sekolah sehingga berdampak ke interaksi anak. Seperti anak menjadi antisosial dengan lingkungan sekitar. Pada situasi pandemi Covid-19 penggunaan gadget sangat berguna untuk pembelajaran online jarak jauh dan bisa berinteraksi dengan teman melalui aplikasi.

\section{Dampak positif dari penggunaan gadget}

Menurut (Witarsa et al., 2018)

a. Mempermudah komunikasi

Dengan adanya gadget anak akan dengan mudah berkomunikasi dengan teman yang lain.

b. Menambah pertemanan 
Dengan adanya aplikasi didalam gadget anak bisa memperluas jaringan pertemanan didunia maya.

c. Menambah rasa percaya diri

Disetiap hari manusia akan membawa gadget kemanapun karena bisa menambah rasa percaya diri.

Menurut (Ardianti et al., 2018) menjelaskan bahwa;

a. Mudah meperoleh informasi Anak dengan mudah mengakses informasi melalui gadget.

b. Menjadikan anak yang kreatif Dengan aplikasi di gadget anak bisa lebih kreatif.

Menurut (Rozalia, 2017) Dampak positif yang ditimbulkan dari gadget adalah:

a. Sebagai hiburan

Gadget sebagai sarana hiburan adalah menggunakan untuk bermain games.

b. Sebagai media komunikasi

Dengan gadget siswa dapat berkomunikasi dengan mudah.

c. Penggunaan internet

Didalam pembelajaran siswa mencari materi melalui internet.

Jadi dari penjelasan ketiga ahli di atas dapat disimpulkan bahwa penggunaan gadget bisa mempermudah anak dalam mencari materi tugas sekolah, sebagai sarana hiburan, anak bisa berteman dengan orang banyak dan menambah rasa percaya diri mereka, anak bisa mengakses informasi dan membuat anak menjadi kreatif.

\section{Dampak Negatif dari Penggunaan Gadget:}

Menurut penjelasan dari (Sinta, 2018) dinyatakan bahwa :

a. Bahaya terkena sinar radiasi

Jika gadget digunakan dalam waktu yang lama maka mengakibatkan berkurangnya kemampuan indera pengliatan karena terkena cahaya radiasi.

b. Menjadikan sebuah kebisaan

Dalam keseharian anak menjadikan gadget sebagai kebiasaan yang tidak bisa terlepas dari genggaman anak sehingga selalu dibawa kemanapun berada.

c. Terlambat dalam memahami materi pembelajaran

Saat pembelajaran berlangsung siswa tidak fokus terhadap materi yang disampaikan guru dikarenakan sering mencari materi dalam gadget.

Menurut (Novitasari, 2016) sebagai berikut :

a. Malas melakukan kegiatan

Dengan berbagai jenis aplikasi didalam gadget membuat anak lebih asyik memainkan gadget daripada kegiatan olahraga sehingga anak lebih mudah terserang penyakit.

b. Lupa bermain bersama teman Pemakaian gadget secara terus menerus bisa melupakan kebiasaan bermain bersama teman didunia nyata. 
Menurut penjelasan dari (Hidayati, 2016) bahwa dampak negatif:

a. Menjadi kecanduan gadget

Saat bermain dengan waktu lama bisa berakibat kecanduan gadget anak menjadi tidak peduli saat diajak bicara.

b. Lebih mementingkan gadget daripada perintah orang tua

Pada saat orang tua memperintah anak untuk membeli sesuatu akan tetapi anak tidak mempedulikan dan melanjutkan bermain gadget.

Dari penjelasan ketiga ahli diatas dapat disimpulkan dampak negatif dari penggunaan gadget terhadap anak adalah anak kecanduan bermain gadget, malas beraktifitas, menjadi sebuah kebiasaan, sulit fokus dalam belajar. Antisosial dengan lingkungan sekitar tempat tinggal.

\section{SIMPULAN}

Berdasarkan dari beberapa
kajian kepustakaan dapat ditarik
kesimpulan bahwa Penggunaan
gadget pada anak Sekolah Dasar dapat berdampak positif dan negatif. Dampak positif antara lain: (1) mempermudah komunikasi; (2) dapat mencari informasi dimana saja; (3) Memperbanyak jaringan pertemanan; (4) Menambah kreatifitas anak; sedangkan dampak negatif dari penggunaan gadget antara lain : (1) anak malas membaca buku karena dapat materi dari internet; (2) anak malas aktifitas; (3) anak mudah marah; (4) Tergangunya konsentrasi; (5) dapat merusak mata.

\section{DAFTAR RUJUKAN}

Ardianti, W., Lapau, B., \& Dewi, O. (2018). Jurnal Photon Vol. 9. No. 1, Oktober 2018. Photon, 9(1), 1-8. http://ejurnal.umri.ac.id/index.ph p/photon/article/view/1057/612

Chusna, P. A. (2017). Pengaruh

Media Gadget Pada

Perkembangan Karakter Anak.

Dinamika Penelitian: Media

Komunikasi Sosial Keagamaan, 17(2), 315-330.

https://doi.org/10.21274/dinamik $\mathrm{a} / 2017.17 .2 .315-330$

Hidayati, R. (2016). PERAN

ORANG TUA : KOMUNIKASI

TATAP MUKA DALAM

MENGAWAL DAMPAK

GADGET PADA MASA

GOLDEN AGE. Jurnal Ilmu

Komunikasi, 1-10.

http://jurnal.utu.ac.id/jsource

Kamil, M. F. (2016). Pengaruh Gadget Berdampak Kepada Kurangnya Komunikasi Tatap Muka Dalam Kehidupan Sehari. http://repository.radenintan.ac.id /437/1/SKRIPSI.pdf

Latifa, U. (2017). Aspek

Perkembangan pada Anak

Sekolah Dasar : Masalah dan

Perkembangannya. Journal of Multidisciplinary Studies, 1(2), 185-196.

Marpaung, J. (2018). Pengaruh Penggunaan Gadget Dalam Kehidupan. KOPASTA: Jurnal Program Studi Bimbingan Konseling, 5(2), 55-64. https://doi.org/10.33373/kop.v5i 2.1521

Marzali, A.-. (2017). Menulis Kajian Literatur. ETNOSIA : Jurnal Etnografi Indonesia, 1(2), 27. https://doi.org/10.31947/etnosia. v1i2.1613

Melfianora. (2017). Penulisan Karya 
Tulis Ilmiah Dengan Studi Literatur. Studi Litelatur, 1-3.

Novitasari, W. (2016). DAMPAK

PENGGUNAAN GADGET

TERHADAP INTERKSI

SOSIAL ANAK USIA 5-6

TAHUN. PAUD Teratai., 05, 182-186.

Purwanto, A., Pramono, R., Asbari, M., Santoso, P. B., Wijayanti, L. M., Choi, C. H., \& Putri, R. S. (2020). Studi Eksploratif Dampak Pandemi COVID-19 Terhadap Proses Pembelajaran Online di Sekolah Dasar. EduPsyCouns: Journal of Education, Psychology and Counseling, 2(1), 1-12. https://ummaspul.ejournal.id/Edupsycouns/article/vi ew/397

Putri Hana Pebriana. (2017). Analisis Penggunaan Gadget terhadap Kemampuan Interaksi Sosial pada Anak Usia Dini. Jurnal Pendidikan Anak Usia Dini, 1(1), 2. https://doi.org/10.31004/obsesi.v $1 \mathrm{i} 1.26$

Rozalia, M. F. (2017). Hubungan Intensitas Pemanfaatan Gadget Dengan Prestasi Belajar Siswa Kelas V Sekolah Dasar. Jurnal Pemikiran Dan Pengembangan Sekolah Dasar (JP2SD), 5(2), 722.

https://doi.org/10.22219/jp2sd.v ol5.no2.722-731

Sinta. (2018). Pengaruh Gadget Terhadap Perkembangan Sosial Anak di TK Aisyiyal Bustanul Athfal VI. Artikel Penelitian, 2018(2018), 1-11.

Suntoro, I. (2013). PERSEPSI

ORANGTUA TERHADAP

DAMPAK PENGGUNAAN

GADGET PADA ANAK USIA PENDIDIKAN DASAR. Jurnal
Ilmu Pendidikan, 1-16.

Susilo, A., Rumende, C. M., Pitoyo, C. W., Santoso, W. D., Yulianti, M., Herikurniawan, H., Sinto, R., Singh, G., Nainggolan, L., Nelwan, E. J., Chen, L. K., Widhani, A., Wijaya, E., Wicaksana, B., Maksum, M., Annisa, F., Jasirwan, C. O. M., \& Yunihastuti, E. (2020). Coronavirus Disease 2019: Tinjauan Literatur Terkini. Jurnal Penyakit Dalam Indonesia, 7(1), 45. https://doi.org/10.7454/jpdi.v7i1. 415

Syahudin, D. (2019). Pengaruh Gadget Terhadap Pola Interaksi Sosial dan Komunikasi Siswa. GUNAHUMAS Jurnal Kehumasan, 2(1), 273-282.

Syifa, L., Setianingsih, E. S., \& Sulianto, J. (2019). Dampak Penggunaan Gadget terhadap Perkembangan Psikologi pada Anak Sekolah Dasar. Jurnal Ilmiah Sekolah Dasar, 3(4), 538-544.

Wahyu Aji Fatma Dewi. (2020). DAMPAK COVID-19 TERHADAP IMPLEMENTASI PEMBELAJARAN DARING DI SEKOLAH DASAR. Jurnal Ilmu Pendidikan, 2(1), 57.

Witarsa, R., Mulyani, R. S., Urhananik, \& Haerani, N. R. (2018). Pengaruh penggunaan gadget terhadap kemampuan interaksi sosial siswa Sekolah Dasar. Pedagogik, VI(1), 9-20.

Xiao, A. (2018). Konsep Interaksi Sosial Dalam Komunikasi, Teknologi, Masyarakat. Jurnal Komunika: Jurnal Komunikasi, Media Dan Informatika, 7(2). https://doi.org/10.31504/komuni ka.v7i2.1486

Yuliana. (2020). Corona virus 
diseases (Covid -19); Sebuah tinjauan literatur. Wellness and Healthy Magazine, 2(1), 187192.

https://wellness.journalpress.id/ wellness/article/view/v1i218wh 